Article

\title{
Vattimo and Caritas: A Postmodern Categorical Imperative?
}

Matthew Edward Harris

\begin{abstract}
After the death of God, the hermeneutical nihilist Gianni Vattimo thinks we are living in an age where it is no longer possible to believe in 'violent' metaphysical notions such as 'objectivity' and 'universality.' However, we still cannot shake off the traces of the past that have been passed down through linguistic traditions. Kantian ethics is a case in point, situated in the midst of what Vattimo, following Heidegger's interpretation of Nietzsche, regards as the history of Being as a weakening without a termination point. Kant's Categorical Imperative is a secularised form of Christian caritas mixed with its evangelical universalising mission. In turn, Kant's emphasis on reason built on the key Christian insight of binding people together by turning inwards through faith. For Vattimo, if one turns inwards then one should listen to others like you, i.e., those who are fellow weak thinkers who want to engage in dialogue. By introducing this condition implicitly, Vattimo weakens the categorical imperative by revealing it in weakened form to be a hypothetical imperative at the cost not only of excluding 'strong' thinkers, but also revealing a stronger conception of the subject in his philosophy that borders on the metaphysical.
\end{abstract}

Keywords: Vattimo, Kant, hermeneutics, secularisation

\section{Kant's Categorical Imperative in the light of Vattimo's hermeneutical nihilism}

I

mmanuel Kant's Categorical Imperative is arguably the height of Enlightenment thought on ethics. At its heart is the subject conceived as

the supremely rational and autonomous individual, the lawgiver whose value derives from self-legislating and having self-respect, with respect for others as such logically following. The rational, law-giving member of the kingdom of ends "must always regard himself as making laws in a kingdom of ends which is possible through freedom of the will," writes Kant in the

(c) 2014 Matthew Edward Harris

http://www.kritike.org/journal/issue 15/harris december2014.pdf

ISSN 1908-7330

$(\mathrm{cc}) \mathrm{BY}$-NC 
Groundwork, ${ }^{1}$ and this ability and realisation "must be found in every rational being." 2 Respecting oneself through obeying one's own laws, therefore, one realises every other being is similarly a self-legislator, and therefore one attributes worth to all rational beings as ends in themselves. In turn, this informs what one is able to rationally universalise when self-legislating, at least on the interpretation of Kant offered by philosophers such as Onora O'Neill and Allen Wood. ${ }^{3}$

Although this brief summary of Kant's position is schematic and perhaps over-simplified for purposes of brevity, it contains the key assumptions that the postmodern philosopher Gianni Vattimo regards as devalued and implausible in his interpretation of the European-wide event of the "death of God." These assumptions include the sovereignty of the subject, the transparency of reason, and the need to universalise in ethics. Born in Turin in 1936, Vattimo studied under Hans-Georg Gadamer in Heidelberg and Luigi Pareyson in Turin. Along with the significant and distinct philosophies of his mentors, his two defining influences have been Friedrich Nietzsche and Martin Heidegger. Vattimo often reads Heidegger through Nietzsche and vice-versa. In the case of the death of God, the Nietzschean image central to Vattimo's weak thought, his controversial philosophical programme since the late 1970s, Vattimo draws heavily on Heidegger's volumes on Nietzsche and his essay "The Word of Nietzsche: 'God is Dead'." Vattimo follows Heidegger in drawing heavily from Nietzsche's unpublished work. Thus, Vattimo in key works such as The End of Modernity, like Heidegger in "The Word of Nietzsche ... ," identifies the "death of God"' not only with nihilism, ${ }^{4}$ but also with the important quotation from an aphorism of The Will to Power, that in nihilism "the highest values are devaluing themselves." 5 Both of these identifications are contestable, not least due to the fact that Nietzsche was ambivalent towards nihilism. In The Gay Science, Nietzsche regards nihilism as the fate of European civilisation to lose faith in that which makes life endurable, particularly its embedded Christian values. ${ }^{6}$ Yet in The Anti-Christ, Nietzsche

${ }^{1}$ H. J. Paton, The Moral Law: Kant's Groundwork of the Metaphysics of Morals (London: Hutchinson University Library, 1972), 95.

${ }^{2}$ Ibid., 96.

${ }^{3}$ Onora O'Neill, The Bounds of Justice (Cambridge: Cambridge University Press, 2000); Allen Wood, Kant's Ethical Thought (Cambridge: Cambridge University Press, 1999).

${ }^{4}$ Gianni Vattimo, The End of Modernity, trans. by J. Snyder (Cambridge: The Polity Press 1988), 20; Martin Heidegger, "The Word of Nietzsche: 'God is dead'," in The Question Concerning Technology and Other Essays, ed. by David Ferrell Krell (New York and London: Garland 1977), 57.

${ }^{5}$ Heidegger, "The Word of Nietzsche,'” 66.

${ }^{6}$ Friedrich Nietzsche The Gay Science, trans. by Josephine Nauckhoff (Cambridge: Cambridge University 2001), 204.

(c) 2014 Matthew Edward Harris http://www.kritike.org/journal/issue 15/harris december2014.pdf

ISSN 1908-7330

(cc) $\mathrm{BY}-\mathrm{NC}$ 
sees nihilism as bound up with vigour sufficiently destructive to obliterate these inherited values. ${ }^{7}$ Rather than sharing Nietzsche's ambivalence towards nihilism, Vattimo sees it as our "sole opportunity." ${ }^{8}$ Why is nihilism liberating? For Vattimo, nihilism, the "death of God," is the end of philosophy, by which, again following Heidegger, he means metaphysics and the "highest values" from the time of Plato to its dissolution in the latemodern world of techno-science. "Metaphysics" is, for Vattimo, a pejorative term. It is seen as negative because it is "violent," because it silences, closing down debate by presuming there is always a correct answer to any question that is asked. From the idea of Plato's philosopher kings to Logical Positivism, metaphysics has been linked to restriction and repression.

If nihilism is liberating, how did it come about? Here Vattimo adduces a number of arguments. This is his method: Instead of demonstrating, he cajoles one into seeing the most plausible way of interpreting the way in which the world is now. In his work A Farewell to Truth, Vattimo writes:

Someone might ask, 'but why are you so convinced that you should be preaching [this message of liberation] to us if you are not a metaphysician?' To which I would reply, 'but haven't you read a, b, c, and d?' In short, the only arguments I can adduce are not ones of the traditional type but ones of transmission, language, the classics we have in common. ${ }^{9}$

By these classics, Vattimo is referring to the wide range of authors that are part of the western tradition to which Vattimo refers and draws upon when outlining his position concerning the death of God. In Beyond Interpretation, Vattimo states that if one has read Marx, Nietzsche, Freud and Wittgenstein, one can no longer entertain certain beliefs about the world, ${ }^{10}$ including the idea that a human is a rational, autonomous self-legislator. These thinkers themselves are part of a longer tradition, that of what Vattimo calls the "nihilistic vocation of Being": the death of God is metaphysics culminating in its own self-destruction. Vattimo has various, interrelated ways of articulating this phenomenon. Along Nietzschean lines, he refers to

${ }^{7}$ Friedrich Nietzsche The Anti-Christ, trans. by R. J. Hollingdale (London: Penguin 1990a), 132.

${ }^{8}$ Vattimo, The End of Modernity, 19.

${ }^{9}$ Gianni Vattimo, A Farewell to Truth, trans. by William McCuaig (New York: Columbia University Press, 2011), 70-71.

${ }^{10}$ Gianni Vattimo, Beyond Interpretation, trans. by David Webb (Cambridge: Polity Press, 1997), 106.

(c) 2014 Matthew Edward Harris http://www.kritike.org/journal/issue 15/harris december2014.pdf

ISSN 1908-7330 
the death of God, such as the image Nietzsche used of God cancelling out his own commandment not to tell lies by being discovered to be a superfluous lie. Vattimo also employs the Heideggerian notion of metaphysical descriptions of "subject" and "object" being dissolved in the Ge-Stell (enframing) enacted by technology, with technology challenging humans and vice versa to the point of everything losing its qualities, which we become aware of in the Ereignis, the event of transpropriation in which we realise we are released from being defined by a metaphysical essence. The Ge-Stell precludes historical newness in its "reduction of everything to Grund." 11 With all human existence now entirely capable of being planned, what counts as a human "subject" and an "object" loses definition, and so Vattimo cites Heidegger stating that the Ereignis involves the "oscillating" realm 'through which man and Being reach each other in their essence ... losing those determinations with which metaphysics had endowed them." 12 Indeed, when Vattimo discusses Ereignis, he quotes from Heidegger's Identity and Difference rather than his Contributions to Philosophy. ${ }^{13}$ Through being released from metaphysically-defined qualities and roles, there has been what Vattimo calls in his book The Transparent Society, a "liberation of differences, of local elements," ${ }^{14}$ such as minority groups using communications technology to come to the microphones and, in more recent times, begin blogging and setting up alternative media outlets. This postmodern phenomenon illustrates that there is no longer any centre, that there are "no facts, only interpretations," 15 a phrase of Nietzsche's Vattimo often mentions.

Vattimo has continuously stressed the need to engage with the history of metaphysics, the forgetting of ontological difference by identifying Being with beings. Being is more originary than beings, for without the clearing of Being in which humans (or "Dasein," to use Heidegger's terminology adopted by Vattimo) dwell, one would not be able to identify and refer to beings at all. The "opening" provided by the clearing of Being into unconcealment permits any expression. The opening is not given once for all, but is "historical" and "eventual"; how we understand the nature of

\footnotetext{
${ }^{11}$ Gianni Vattimo, "Towards an Ontology of Decline," in Recoding Metaphysics, ed. by Giovanna Borradori (Evanston, Illinois: Northwestern University Press, 1988), 71.

${ }^{12}$ Ibid., 72. Vattimo quotes from Heidegger, Identity and Difference, trans. by Joan Stambaugh (New York, Evanston, and London: Harper and Row, 1969), 37. The translation is slightly modified in Vattimo's essay.

${ }^{13}$ Vattimo, "Towards an Ontology of Decline," 71-72. See also Gianni Vattimo, The Adventure of Difference, trans. by Cyprian Blamires (Baltimore: The John Hopkins University Press, 1993), 171-174. Press, 1992), 8

${ }^{14}$ Gianni Vattimo, The Transparent Society, trans. by David Webb (Cambridge: Polity

${ }^{15}$ Gianni Vattimo, The Responsibility of the Philosopher, trans. by William McCuaig (New York: Columbia University Press, 2010a), 81.
}

(c) 2014 Matthew Edward Harris

http://www.kritike.org/journal/issue 15/harris december2014.pdf

ISSN 1908-7330

(cc) $\mathrm{BY}-\mathrm{NC}$ 
things depends on changes in language over time. While Heidegger in his later works places critical emphasis on language, Vattimo's own philosophical style finds its most succinct expression in the identification he makes between Being and language through his own translation into Italian of Gadamer's phrase from Warheit und method (Truth and Method) "Sein, das verstanden werden kann, ist Sprache." 16 Vattimo's translation was "L'essere che può venire compreso è linguaggio." 17 Rendered from the Italian into English, the translation reads "Being that can be understood is language." Vattimo wished to keep the commas from the German, even though a strict translation into Italian and English would not necessitate them. The commas are present in the German due to the conventions of grammar. Against removing the commas, Vattimo writes in his book The Responsibility of the Philosopher that he wanted to emphasise that Being is language, to ward not only against relativism, but also against "the supposition ... that somewhere beyond all linguistic comprehension there might subsist a Being 'in itself'."18

As Vattimo implies when talking about the "classics," the horizons of our thought are established through the linguistic traces we inherit. This is his interpretation of the "thrownness" in Heidegger's analytic of Dasein. We inherit the tradition of western metaphysics, as well as a canon of literary classics, such as Dante, Shakespeare, and the Bible. Within this tradition we find themes such as the uniqueness and importance of the human being, variously understood in terms of his being made in the image of God, secularised into the autonomous rationality of the Cartesian and Kantian human being. Other dominant themes include universality and objectivity, first understood as Platonic forms, historicised through Christianity, being secularised in Kant's thought, and quantified through science and positivism. Vattimo frequently recounts Nietzsche's narrative of "How the 'Real World' finally became a Fable" from his Twilight of the idols in which this story is outlined. ${ }^{19}$ In the nihilism of the story's end, which Vattimo understands as the death of God, both "rationality" and "rationality" need to be "reconstructed," as Vattimo puts it in his book Nihilism and emancipation. ${ }^{20}$ These linguistic metaphysical traces-from Plato, Christianity, Descartes, Kant, and many more besides - cannot be discarded in a sort of dialectical overcoming, for to do so would be just to start again on another foundationalism, to repeat, not weaken, metaphysics. This is why Vattimo's

\footnotetext{
16 Hans-Georg Gadamer, Wahrheit und methode: grundzuge einer philosophischen Hermeneutic (Tubingen: J. C. B. Mohr, 1972), 450.

${ }^{17}$ Gianni Vattimo, Verità e metodo (Milan: Bompiani, 1983), 542.

${ }^{18}$ Vattimo The Responsibility, 57.

${ }_{19}$ Friedrich Nietzsche, Twilight of the Idols, trans. by R. J. Hollingdale (London: Pengunin, 1990b), 50-51.

${ }^{20}$ Gianni Vattimo, Nihilism and Emancipation, trans. by William McCuaig (New York: Columbia University Press, 2004), xxvi.
} 


\section{VATTIMO AND CARITAS}

philosophical programme is one of pensiero debole ("weak thought"), in which he talks of "weakening" not "destroying" metaphysics, for the traces of the latter are ineradicable, not least because they constitute the horizons of thought within the traditions found in our shared western culture. As Vattimo writes in The End of Modernity, "Tradition is the transmitting of linguistic messages that constitute the horizon within which Dasein is thrown as an historically determined project." ${ }^{21}$ Rather than an overcoming, in a term borrowed from Heidegger, Vattimo proposes that thought undertakes a Verwindung (an ironic distortion, or "twisting" of, and convalescence from) metaphysics. ${ }^{22}$

\section{Vattimo's Verwindung and Christianity}

It is just this kind of ironic distortion that Vattimo performs on Christianity, in what Giovanni Giorgio refers to as Vattimo's most recent phase of thought. ${ }^{23}$ Why choose Christianity, and how has Vattimo twisted it? Vattimo appeals to Christianity for personal, philosophical, and ethical reasons. Growing up in Italy during the 1940s and 1950s, religion was everpresent, and he was sent to Catholic school and participated in Catholic youth groups. While he lost his faith during his university studies, particularly when he lost the links with the Italian Catholic culture when he moved to take up the Humboldt fellowship in Germany, his mind returned to existential questions concerning his own health and mortality, and that of others, in his advancing years. ${ }^{24}$ Philosophically, Vattimo was eager to ground hermeneutics historically. Due to his assumptions that all forms of metaphysics are violent, he did not want there to be any "rightist" interpretation of Heidegger (and by left and right, think along Hegelian lines) in which a "return of Being" was possible, a tendency he sees in what he regards, somewhat unfairly, as the metaphysical philosophies of alterity in the thought of Derrida and Levinas. ${ }^{25}$ Finally, Vattimo wants his hermeneutical nihilism to yield an ethic. ${ }^{26}$ One of the principal advantages of the philosophies of Derrida and Levinas is that alterity, grounded in the transcendent "Other," provides an ethic of concern for the "other" that trumps any individual or cultural standard. A purely "leftist," historical and

${ }^{21}$ Vattimo, The End of Modernity, 120.

22 Ibid., 172-179.

${ }^{23}$ Giovanni Giorgio, Il pensiero di Gianni Vattimo (Milan: Franco Angeli, 2006), 12.

${ }^{24}$ Gianni Vattimo, Belief, trans. by David Webb and Luca D’Isanto (Cambridge: Polity Press, 1999).

${ }^{25}$ Vattimo After Christianity, trans. by Luca D'Isanto (New York: Columbia University Press, 2002), 36-37.

${ }^{26}$ Vattimo, Beyond Interpretation.

(c) 2014 Matthew Edward Harris

http://www.kritike.org/journal/issue 15/harris december2014.pdf

ISSN 1908-7330

(cc) BY-NC 
immanent hermeneutical nihilism does not seem to provide anything more than subjectivism or relativism, insufficient for establishing any kind of ethical normativity.

From the early 1990s onwards, Vattimo's "Verwindung" of Christianity has aimed to address these concerns through the hermeneutical figure of Jesus Christ. As he puts it in his book Belief, "The interpretation given by Jesus Christ of Old Testament prophecies, or (better) the interpretation which he himself is, reveals its true and only meaning: God's love for his creatures." 27 There are two sides to the same coin of bringing Jesus Christ into his philosophical programme: the historical and the ethical. The historical refers to Vattimo's appropriation of a term used to refer to one of St. Paul's Christological themes: "kenosis." Usually, the context of kenosis is the Christ Hymn of Paul's letter to the Philippians (chapter two, verses five to eleven), in which Christ is said to empty his power to come from heaven to earth, incarnating himself in the "form of a slave." Vattimo does not quote Philippians 2:5-11, although he cites the text once in Belief..$^{28}$ Instead of focusing on this one particular text, by kenosis Vattimo means a message of indefinite weakening inaugurated through the message of Jesus and Jesus' message. Due to Vattimo's anti-metaphysical stance, he does not think the message of Jesus corresponds to an incarnation in the literal sense of the term. As such, Vattimo has been accused by theologians such as Thomas Guarino of filling up old wineskins with new wine - "a new and alien vintage" without regard for what Christians actually believe. ${ }^{29}$ However, this is precisely the point of a Verwindung; Vattimo cannot shed the linguistic tradition, even though he can weaken it through interpreting it anew. Nevertheless, what exactly Vattimo means by "the interpretation which he himself is" remains unclear. Luca D'Isanto speculates that for Vattimo it refers to the message of the divine abandoning transcendence entering into history, thus, weakening himself. ${ }^{30}$ This reading cannot be derived explicitly from Belief, although it can be seen in a later, lesser known essay of Vattimo's called "After Onto-Theology." ${ }^{31}$ The message of the Christ entering into history parallels the "indefinite process of consummation and dissolution" of the structures of Being, "which does not culminate in 'fully realized

\footnotetext{
${ }^{27}$ Vattimo, Belief, 64.

${ }^{28}$ Ibid., 39.

${ }^{29}$ Thomas Guarino, Vattimo and Theology (London and New York: T\&T Clark, 2009),

152.

${ }^{30}$ Luca, D'Isanto, "Introduction," in Gianni Vattimo, Belief (Cambridge: Polity Press, 1999), 11.

${ }^{31}$ Gianni Vattimo, "After onto-theology: philosophy between science and religion," in Religion After Metaphysics, ed. by Mark Wrathall (Cambridge: Cambridge University Press, 2003), 35.
}

(c) 2014 Matthew Edward Harris http://www.kritike.org/journal/issue 15/harris december2014.pdf ISSN 1908-7330 


\section{VATTIMO AND CARITAS}

nothingness'," 32 for the latter itself would be metaphysical. Vattimo calls this process "secularisation." It is this process that culminates in the nihilism of the late-modern world and it is through this imagery that Vattimo argues that the tradition of the West favours this "left Heideggerian" interpretation. The plurality found in the secularised late-modern world has its archetype in the way in which God has spoken to his people in different ways at different points in history, which is another interpretation Vattimo gives to kenosis in Beyond Interpretation. ${ }^{33}$

If secularisation is not to be understood in some quasi-Hegelian metaphysical emptying of transcendence into immanence in the manner in which 1960s death of God theologian Thomas Altizer conceived of it, the force by which it moves must be provided by something else. While the kenotic power of Christ derives from the message of God entering into history, Christ's kenotic power stems from his message which then feeds into ethics. Rather than dwelling on Philippians 2:5-11, Vattimo places more emphasis on John 15:15: "I no longer call you servants but friends." 34 The message of kenosis, then, is one of levelling, of devaluing the highest values; God takes the form of a slave and he is no longer calling others servants. The message of Jesus, and Jesus' message as recorded in the New Testament, are seen as paradigmatic for devaluing the highest values - "If one thinks of nihilism as an infinite history in terms of the religious 'text' that is its basis and inspiration, it will speak of kenosis as guided, limited and endowed with meaning, by God's love." 35 For God's love, Vattimo often uses the term caritas ("charity," or "love"). For Vattimo, secularisation has no limit except for charity. This principle of charity is the point of convergence between philosophical nihilism and the religious tradition of the West. ${ }^{36}$ Vattimo further reinforces the link between the discourses of kenosis and the history of Being by drawing upon the thought of the French anthropologist René Girard, particularly his book Things Hidden Since the Foundation of the World. ${ }^{37}$ Girard argues that Jesus was killed for exposing the "victimary mechanism" underlying all natural religions. The latter were established to contain the overflow of mimetic violence through scapegoating an individual upon which society can vent in order to preserve itself. Ritualised over time and developed into that which is sacred underscoring the religious overseen by priests, Jesus appeared the perfect victim, yet his message of love revealed

\footnotetext{
32 Vattimo, Belief, 63.

${ }_{33}$ Vattimo Beyond Interpretation, 48.

${ }^{34}$ Vattimo Belief, 78.

${ }^{35}$ Ibid., 64.

36 Vattimo Beyond Interpretation, 51.

${ }^{37}$ René Girard, Things Hidden Since the Foundation of the World (London and New York:
} The Athlone Press, 1987).

(c) 2014 Matthew Edward Harris http://www.kritike.org/journal/issue 15/harris december2014.pdf

ISSN 1908-7330

(cc) $\mathrm{BY}-\mathrm{NC}$ 
the natural sacred for what it is. Girard did not develop his insights into a theory of secularisation, but Vattimo draws parallels between the "ontotheological" qualities of God (such as his omniscience and transcendence) and the violence of metaphysics, ${ }^{38}$ to the point where in his essay "Heidegger and Girard" he thinks the latter has helped him "complete" Heidegger. ${ }^{39}$

\section{Vattimo and caritas: Ethics without transcendence}

Girard's work "completes" Heidegger by yielding a hermeneutical ethic that cannot be found in either the work of the latter or in the thought of Nietzsche. Girard bridges the gap between the New Testament and Heidegger's thought by linking Jesus' message of love to the revelation of religious violence that is at the same time metaphysical, thus, fusing the discourses between secularisation and the nihilistic vocation of Being as a weakening of strong structures in history. Vattimo has been heavily criticised for his understanding of caritas, with some theologians, such as Frederiek Depoortere, seeing it as "something absolute, something transcendent." 40 Anticipating such criticism, Vattimo writes in Belief that, "Perhaps the reason why nihilism is an infinite, never-ending process lies in the fact that love, as the 'ultimate' meaning of revelation, is not truly ultimate." 41 Caritas, then, is not a moral absolute or transcendent principle, but it is the only limit of secularisation. Secularisation is the nihilistic process of weakening strong structures. It would appear that caritas is the self-limiting of secularisation, with its tendency for weakening as its limiting factor. If caritas is to be treated as a kind of ethic, what would it be and how would it be related to nihilism as a process? Cryptically, Vattimo writes in Belief that "love ... is a 'formal' commandment, not unlike Kant's categorical imperative, which does not command something specific once and for all, but rather applications that must be 'invented' in dialogue." 42 Elsewhere, in an essay called "Ethics without Transcendence," Vattimo elaborates a little more on how he sees caritas functioning both historically and formally: "It should not be forgotten that the categorical imperative of Kant in its most memorable formulations does little more than express in secular terms that Christian imperative of

\footnotetext{
${ }^{38}$ Vattimo, Belief, 39.

${ }^{39}$ Gianni Vattimo, "Heidegger and Girard," in Christianity, Truth, and Weakening Faith: A Dialogue, ed. by Santiago Zabala (New York: Columbia University Press, 2010), 78.

${ }^{40}$ Frederiek Depoortere, Christ in Postmodern Philosophy: Gianni Vattimo, René Girard, and Slavoj Žižek (London and New York: T\&T Clark, 2008), 20.

${ }^{41}$ Vattimo, Belief, 65.

${ }^{42}$ Ibid., 66.
} 


\section{VATTIMO AND CARITAS}

caritas." 43 Through traces of both Kant and the Christian principle of love, Vattimo aims to derive a limit of secularisation that is both ethical and hermeneutical. If Vattimo can successfully create a post-Kantian ethic which takes into account not only the death of God as an ontological event, but also retain the sense of duty and ethical structure from Kant's work, then he would have made an important contribution to post-Kantian thought. This is especially so as Kantian thinkers in the Anglo-American tradition, such as David Wiggins, have expressed scepticism concerning the possibility of postKantian universalism in ethics, only seeing some sort of preference utilitarianism with an "impartial spectator" as a live possibility. ${ }^{44}$ While Vattimo did not want to retain the strong notion of an objective, universal moral law, he did want to "twist" this Kantian structural feature to retain a universally available criterion (in the normative sense) for adjudicating between interpretations based on a respect for others, the latter feature being picked out by Kant scholars such as Jerome Schneewind as an integral feature of Kant's work. ${ }^{45}$

It was with later works, such as After Christianity (2002), The Future of Religion (2004), and After the Death of God (2007), that Vattimo developed his historicised understanding of the Categorical Imperative further. Vattimo's method is to trace the Kantian concerns with interiority and universality that underlie the Categorical Imperative not only back to the Christian revelation, but also forward to the collapse of compelling reasons for their "rationalist" interpretation. For the former part of his method, Vattimo appeals to the German hermeneutic philosophy of Wilhelm Dilthey (d. 1911), who thought the most significant consequence of the Christian revelation was that it involved people turning inwards to discover the truth. In his Introduction to the Human Sciences, Dilthey argued that Jesus Christ unified people through faith, an inner truth. ${ }^{46}$ This focus on the inner life, which Vattimo refers to as the "principle of interiority," constitutes a universality in the sense that the Christian faith is for all people, regardless of race, nationality, class, or gender. Corresponding approximately to Nietzsche's story of how the world became a fable, it is with Christianity that the absolute became interiorised, historicised, and universalised in terms of faith. Vattimo notes in After Christianity, his book that most discussed Dilthey's ideas that "the new principle of subjectivity introduced by Christianity did not immediately

\footnotetext{
${ }^{43}$ Gianni Vattimo and Santiago Zabala, "Ethics without transcendence?," in Common Knowledge, 9 (2003), 403.

${ }^{44}$ David Wiggins, Needs, Values and Truth (Oxford: Blackwell, 1991).

${ }^{45}$ J. B. Schneewind, “Autonomy, Obligation and Virtue: An Overview of Kant's Moral Philosophy," in The Cambridge Companion to Kant, ed. by Paul Guyer (Cambridge: Cambridge University Press, 1992), 309-341.

${ }^{46}$ Wihelm Dilthey, Introduction to the Human Sciences, trans. by Ramon J. Betanzos (Detroit and London: Harvester-Wheatsheaf. 1979), 229.
}

(c) 2014 Matthew Edward Harris

http://www.kritike.org/journal/issue 15/harris december2014.pdf

ISSN 1908-7330

(cc) BY-NC 
succeed." ${ }^{47}$ Nevertheless, Vattimo points to thinkers such as Augustine in whom the tension between "the novelty of Christian interiority and the hegemony of Greek aesthetic or 'visual' objectivism" was embodied. ${ }^{48}$

"A struggle between Christianity's offering of a new possibility to thought and metaphysics' endurance," writes Vattimo in After Christianity, "goes on up to Kant, who draws the anti-metaphysical implications of the inaugural move of the Christian message." 49 On the one hand, the Greek aestheticist idealist objectivism stipulated that absolute truth was located exterior to the intellect in the forms. On the other hand, Christianity emphasised "inwardness, will, certitude of the cogito" that had been recollected by Descartes, ${ }^{50}$ and from whose thought Kant was drawing further conclusions. The turn inward, begun with Christ, moving slowly through Augustine, Descartes and Kant, weakened the dominant PlatonicAristotelian notion of truth as correspondence, that is, of objectivity. If truth is found within one, then one need not match statements to external things outside. Of course, as Vattimo realises, with Descartes and Kant's thought there occurred merely a relocation of metaphysics; the metaphysical needs did not disappear, but simply moved to the subject, such as Descartes' requirement for "clear and distinct" ideas and his foundationalism. Kant, similarly, thought that a universal, absolute moral law could be established on the subject's rational will. The death of God undermined faith in this rational will, however, through the various insights of Marx, Freud, Nietzsche, among others. Unfortunately, Vattimo does not explicitly state how and why subjectivity as secularisation culminates in the death of God and the liberating need for a Verwindung of metaphysics. This omission may well be because it would require him to accept Heidegger's estimations both of Nietzsche as a metaphysician, albeit one who simultaneously heralded the end of metaphysics and of nihilism. For Heidegger, Nietzsche's theory of the will to power was the ultimately nihilistic theory (in a negative sense) for it reduced the suprasensory, such as God and the forms, to "highest values," reducing Being to value. That which valued was the will to power, the will that wills itself in order to survive. ${ }^{51}$

It was said above that Vattimo's method also involved moving forward to the way in which we can "piously remember" the linguistic traces of tradition, in this case of the Categorical Imperative. The latter already had the character of a secularised, weakened Christian universalism, which in turn is a historicised Platonism, "for the people," as Nietzsche said in Beyond

\footnotetext{
${ }^{47}$ Vattimo, After Christianity, 107.

${ }^{48}$ Ibid., 107.

${ }^{49}$ Ibid., 108.

${ }^{50} \mathrm{Ibid}$.

${ }^{51}$ Heidegger, “The Word of Nietzsche'."
} 
Good and Evil.52 Nevertheless, since Kant, there has been the world-historical event of the death of God, liberating all traditions from being placed in a metaphysically ordered hierarchy. With the culmination of metaphysics goes a need to reconfigure notions such as rationality, universality, and objectivity. Vattimo's starting point in twisting these traces of Enlightenment rationality is the present situation in which objectivity is not possible or plausible due to the decentred hermeneutical plurality that is the defining feature of latemodernity (or "postmodernity"), and that this nihilism is the result of recognising our finitude through secularisation inaugurated by Christianity's principle of interiority. Vattimo states in The Future of Religion that with caritas he is developing "a metarule that obliges and pushes us to accept the different language games" that have been liberated by the event of the death of God..$^{53}$ In A Farewell to Truth, Vattimo responds to Augustine's precept, "look within yourself," which Vattimo regards as 'an advance on the truth of the object,' with the question, "if you turn toward your inner self, oughtn't you also try to heed 'the other as yourself'?"54

Vattimo's logic here is reminiscent of Kant's. For Kant, if one recognises that one is a rational self-legislator and is willing to obey one's own laws, then one should be able to see this capacity for self-legislation in others, giving them the same moral value to which one would impute onto oneself. Vattimo's appropriation of Augustine's "look within yourself," which is based upon a universal brotherhood of faith according to Dilthey's understanding of Christianity's appeal, is far less defined. Augustine's turn inward had value on the assumption that it was possible for the human being to have an inner connection with God. As Vattimo has no need for, or belief in, an objectively existing metaphysical God, then this justification for turning inward has no purpose. All we are left with, in fact, is an inward-gazing, with no adequate reason for it; our subjectivism is nihilistic and empty. Nevertheless, we still do in fact turn inwards. If we do turn inwards, surely we should look to others who just so happen to do the same to find a way to establish ethical norms. Indeed, in finding no objective truths within or without, all we can do is to turn to one another to fuse one's limited horizons in dialogue.

To whom should one turn in caritas, and how should one conduct oneself in this turning? Moreover, what would be the result of this action? The answers to these questions will reveal Vattimo's postmodern Categorical

${ }^{52}$ Friedrich Nietzsche, Beyond Good and Evil, trans. by R. J. Hollingdale (London: Penguin, 1990), 32.

${ }^{53}$ Gianni Vattimo, Richard Rorty, and Santiago Zabala, “'What is Religion's Future After Metaphysics?," in The Future of Religion, ed. by Santiago Zabala (New York: Columbia University Press, 2005), 59.

${ }^{54}$ Vattimo, A Farewell to Truth, 76.

(c) 2014 Matthew Edward Harris

http://www.kritike.org/journal/issue 15/harris december2014.pdf

ISSN 1908-7330

(cc) BY-NC 
Imperative. In After the Death of God, Vattimo writes "once you turn inward you must also try to listen to others like you." 55 What does Vattimo mean by others "like you"? Clearly he cannot mean anything like a Platonic universal of humanity or a Kantian rational subject. In Vattimo's book The End of Modernity, he calls for the need for a "crash diet" for the subject, ${ }^{56}$ of a reduced subjectivity, even if he does not flesh out the details. It would appear that Vattimo would prefer to follow Heidegger in conceiving of the individual more in terms of Dasein's relation to Being than as an autonomous subject who moves out of herself to have relationships with other people and relations to other things. Vattimo believes people should interpret latemodernity accordingly as the nihilistic epoch of Being. Writing in Nihilism and Emancipation, this becomes clear as Vattimo states:

The situation to which we really belong before all else, and toward which we are responsible in our ethical choices, is that of the dissolution of principles, of nihilism. If we choose instead to find our ultimate points of reference in the most specific kinds of attachment (to race, ethnic group, family, or class), then we limit our perspective right at the outset. ${ }^{57}$

With a "dissolution of principles," there is no centre, no objectivity and no absolute against which anything can be measured in terms of its truth value. This situation has liberated a plurality of interpretations, which is why Vattimo believes his hermeneutical nihilism is the koiné of late-modernity. Accordingly, ethics should take the form of "discourse-dialogue between defenders of finite positions who recognize that this is what they are and who shun the temptation to impose their position on others." 58 This form of ethics "will certainly retain ... some aspects of Kantism (especially the formulation of the categorical imperative in terms of respect for the other ... stripped of any dogmatic residue)." 59 Vattimo's crash-diet subject is, then, one who has piously recollected Being in its current nihilistic sending; recognising her own finitude by turning inward and finding no divine spark or foundational rationality there, she will turn to others like her.

What will these postmodern, weakened subjects do? Vattimo has implied that they will engage in dialogue, but for what end? Vattimo writes

${ }^{55}$ Gianni Vattimo, "Toward a nonreligious Christianity," in After the Death of God, ed. by Jeffrey W. Robbins (New York: Columbia University Press, 2007), 42.

${ }^{56}$ Vattimo, The End of Modernity, 47.

${ }^{57}$ Vattimo, Nihilism and Emancipation, 41.

${ }^{58}$ Ibid., 46.

${ }^{59} \mathrm{Ibid}$.

(c) 2014 Matthew Edward Harris http://www.kritike.org/journal/issue 15/harris december2014.pdf

ISSN 1908-7330 
in A Farewell to Truth that "we don't reach agreement when we have discovered the truth, we say we have discovered the truth when we reach agreement. In other words, charity takes the place of truth." 60 Elsewhere, in Christianity, Truth and Weakening Faith, Vattimo puts his position more clearly by stating that, "It is still possible to speak of truth ... but only because we have realized caritas through agreement. Caritas with respect to opinion, with respect to choices about values, will become the truth when it is shared." 61 The "universal," writes Vattimo in Nihilism and Emancipation, is only regarded "by passing through dialogue, through consent, if you like through caritas ... truth is born in consent and from consent." 62 In fact, Vattimo priorities "listening" over talking, for Christian charity, in its secularised universal mission, involves acknowledging that others might be right so that "universality" should give rise to charitable hospitality, as Vattimo writes in After Christianity. ${ }^{63}$ Listening to others will further weaken one's own position, as will gathering multiple interpretations in order to fuse horizons to create more syncretistic, less logically coherent positions. This is how caritas is the stimulus to weakening, the nihilistic force behind secularisation. Vattimo's postmodern Categorical Imperative, then, is forming truth as dialogue. This dialogue is the coming together of "weak" subjects fusing their horizons as a result of recognising their finitude as a consequence of turning inward and reading the "signs of the times," 64 that we are living in the epoch of the consummation of the nihilistic vocation of Being.

\section{The conditional and the postmodern subject: Problems for Vattimo's ethics}

Vattimo's notion of caritas rescues some core strengths from Kant's ethics for the late-modern philosopher. It retains the benefits of the second and third formulations of the Categorical Imperative by grounding concern for, and the ethical significance of, others through recognising the importance of oneself. Arguably, though, there are problems with respect to Vattimo's Categorical Imperative. The first is that Vattimo's Categorical Imperative actually seems more like a hypothetical imperative: "if one is prepared to listen to one-another, then engage in dialogue." The second problem is that the decision whether or not to engage in dialogue seems to presume some

${ }^{60}$ Vattimo, A Farewell to Truth, 77.

${ }^{61}$ Vattimo, "Heidegger and Girard," 51.

${ }^{62}$ Vattimo, Nihilism and Emancipation, xxvi.

${ }^{63}$ Vattimo, After Christianity, 101-102.

${ }^{64}$ Gianni Vattimo, "The Trace of the Trace," in Religion, ed. by Jacques Derrida and Gianni Vattimo (Cambridge: The Polity Press, 1998), 91-92.

(c) 2014 Matthew Edward Harris

http://www.kritike.org/journal/issue 15/harris december2014.pdf

ISSN 1908-7330

(cc) $\mathrm{BY}-\mathrm{NC}$ 
kind of autonomy of decision-making, or at the very least a stronger notion of subjectivity than Vattimo is prepared to admit.

Vattimo seems to introduce the conditional into the Categorical Imperative: if others are like you, then listen to them. Can you have an unconditional Categorical Imperative? Unsurprisingly, the answer is "No," for it would be a contradiction in terms. A conditional imperative is a hypothetical imperative, such as, "If you want to go to the cinema, then you have to buy a ticket." This is instrumental reasoning based on an individual or a community deciding a goal and then deducing what would be the rational course of action required in order to achieve this goal. In the case of Vattimo, this goal-setting and instrumental rationality occurs at a different point in the ethical decision-making process than in Kant's ethics. For Vattimo, the goal-setting occurs through the dialogue, but the decision to enter into dialogue is based on whether the other party is willing to engage. "Strong" thinkers would not be dialogue partners, for they presume the "correctness" of their views at the outset, precluding dialogue and, therefore, truth. In recent years, in collaboration with his pupil Santiago Zabala in the work Hermeneutic Communism, Vattimo has preferred to use the term 'conversation' rather than dialogue, for the latter term is reminiscent of Platonic dialogues in which truth is presupposed at the outset. ${ }^{65}$ Truth for Vattimo and Zabala is identical with "friendship," and the latter is forged in the fusion of horizons that constitutes weakening of Being in accordance with the secularising power of caritas, that is, its nihilistic vocation as a process in history.

It has been written elsewhere that the separation of people into "strong" and "weak" thinkers is regrettable not only because it retains a metaphysical dualism, but also because the semantic field of "friendship," "truth," and "charity" indicates that those who are not prepared to engage in dialogue can be ignored and not listened to. ${ }^{66}$ Moreover, the value judgement behind Vattimo's assessment of "strong" thinkers reveals the inconsistencies in Vattimo's philosophy. "The unconditional is violent" is ironically an unconditional assessment. One can liken this inconsistency to Bernard Williams' criticisms of subjectivism in his book Morality: if a subjectivist says someone "has no right" to criticise another's opinion, then this idea of "no right" takes one beyond a merely subjectivist ethic; it is some sort of metaethic or transcendental, pre-content schema in which ethical opinions are separated and managed. ${ }^{67}$ If Vattimo criticises strong thought on the basis of

\footnotetext{
${ }^{65}$ Gianni Vattimo and Santiago Zabala, Hermeneutic Communism: from Heidegger to Marx (New York: Columbia University Press, 2011), 25-26, 79.

${ }_{6} 6$ Matthew E. Harris, "Vattimo and Otherness: Hermeneutics, Charity and Conversation," in Otherness: Essays and Studies, 4 (2013), 1-21.

${ }^{67}$ Bernard Williams, Morality (Harmondsworth, Middlesex: Penguin, 1973), 41.
} 
it being "violent," and if Vattimo backs out of a genuine Categorical Imperative of universal respect for others based on an "inner turn" primarily on the basis that some people are strong thinkers, then he is just like Williams' subjectivist holding that people have "no right" to condemn someone else's beliefs. In other words, Vattimo's view that "violence is wrong" is his implicit moral absolute, in the same way the subjectivist still conceives of a "right" and "wrong" when it comes to judging peoples' opinions. Of course, Vattimo would not even consider himself a relativist, let alone a subjectivist. Vattimo would argue that he is appealing to history to ground a criterion for interpretation that takes him beyond relativism and subjectivism. Vattimo's problem is in trying to create a criterion for interpretation out of hermeneutical nihilism. "For this problem," writes Wolfgang Welsch in Weakening Philosophy: Essays in Honour of Gianni Vattimo, "[that is] of the multiplicity of competing interpretations and the absence of a noninterpretative metacriterion - Vattimo has no solution." 68 Welsch does not think that a "noninterpretative metacriterion" is possible after the death of God. Vattimo may argue that we should try to recollect traces of Being to weaken them to reduce violence. However, if Being just happens, then why should one listen to it? Being has weakened itself despite "strong" thinkers from the time of Late-Antiquity up to the present; indeed, as Vattimo pointed out, the "principle of interiority" took its time to develop between Augustine and Descartes, but it did. Therefore, if we are "thrown" into the world as Dasein, and if Being is inescapably linguistic, surely it is impossible to fail to recollect it in some way, and it takes further, strong reasons to argue for weak thinking and the reduction of violence. If one argues that we should all be weak thinkers (and therefore conversation partners), that we should interpret the traces of Being charitably; then, sooner or later one runs into an ethical absolute.

Indeed, if one argues that one can choose to be either a strong or weak thinker, and that one should be excluded or included as a result of this choice (or at least identity); then, this implies that Vattimo believes that individuals are subjects capable of ethical responsibility, even if it is in the postmodern ontological-ethical sense of the way one comports oneself to Being. It has been argued by Gavin Hyman in a review of Nihilism and Emancipation that Vattimo does not "distort" metaphysics sufficiently in his notion of the subject that underlies his ethics. First of all, Hyman distinguishes between the "nominative" and "accusative" ethics of the subject, whereby the former is autonomous and discrete, whereas the latter is called by something that is

${ }^{68}$ Wolfgang Welsch, "The Human-Over and Over Again," in Weakening Philosophy: Essays in Honour of Gianni Vattimo, ed. by Santiago Zabala (Montreal \& Kingston, London, Ithaca: McGill-Queen's University Press, 2007), 100.

(c) 2014 Matthew Edward Harris

http://www.kritike.org/journal/issue 15/harris december2014.pdf

ISSN 1908-7330

$(\mathrm{cc}) \mathrm{EY}_{\mathrm{N}-\mathrm{NC}}$ 
constituted by that which is prior to contemplation. ${ }^{69}$ Hyman questions whether Vattimo has been able to move to an "accusative" ethics of the subject. Although Vattimo argues that we should read the "signs of the times" and that we are thrown into the infinitely plural world of late-modern, Hyman points out that Vattimo's subject seems to still need ethical guidance. 70 "For Vattimo" writes Hyman, "ethics ... is something we develop or invent by means of our own "choices" and 'decisions.'"71 Vattimo does mention the need for decisions and choices such as "between what holds good and what does not in the cultural heritage from which we come."72 Hyman finds it puzzling that Vattimo should conceive of such a strong, founding subject when he rejects other "metaphysical" notions such as the Levinasian "Other," for the latter is equally "metaphysical" and is a more promising way of grounding a postmodern ethic. ${ }^{73}$ Presumably, on this nominative sense of the subject, one can choose to adhere to one's heritage and become a "strong" thinker. While Vattimo would argue that this is not reading the "signs of the times," this assumption presumes that one can only create one ontology of actuality. Surely, though, in the spirit of plurality one is able to interpret late-modernity in different ways? One could interpret plurality as the dissolution of first principles and foundationalism, or one could see everyone else as wrong and only you and your "cultural heritage" as being right. With no neutral point from which to adjudicate interpretations, even caritas needs to be grounded on something else, something which is lacking. Vattimo's postmodern Categorical Imperative, therefore, lacks both a foundation that does not beg the question or consistency with his intention to weaken metaphysics.

Department of Philosophy, Staffordshire University, United Kingdom

\section{References}

Depoortere, Frederiek, Christ in Postmodern Philosophy: Gianni Vattimo, René Girard, and Slavoj Žižek (London and New York: T\&T Clark, 2008).

Dilthey, Wilhelm, Introduction to the Human Sciences, trans. by Roman J. Betanzos (Detroit and London: Harvester-Wheatsheaf, 1979).

${ }^{69}$ Gavin Hyman, "Must a Post-Metaphysical Political Theology Repudiate Transcendence? The Case of Gianni Vattimo," in The Journal for Cultural and Religious Theory, 8 (2007), 129.

${ }^{70}$ Ibid., 130

${ }^{71}$ Ibid.

${ }^{72}$ Vattimo, Nihilism and Emancipation, 46.

${ }^{73}$ Hyman, "Must a Post-Metaphysical Political Theology Repudiate Transcendence?," 130.

(c) 2014 Matthew Edward Harris http://www.kritike.org/journal/issue 15/harris december2014.pdf

ISSN 1908-7330 


\section{VATTIMO AND CARITAS}

D'Isanto, Luca, "Introduction," in Gianni Vattimo, Belief, trans. by Luca D'Isanto (Cambridge: The Polity Press, 1999).

Gadamer, Hans.-Georg, Wahrheit und methode: grundzuge einer philosophischen hermeneutic (Tubingen: J. C. B. Mohr, 1972).

Giorgio, Giovanni, Il pensiero di Gianni Vattimo (Milan: Franco Angeli, 2006).

Girard, René, Things Hidden Since the Foundation of the World (London and New York: The Athlone Press, 1987).

Guarino, Thomas, Vattimo and Theology (London and New York: T\&T Clark, 2009).

Harris, Matthew E., "Vattimo and Otherness: Hermeneutics, Charity and Conversation," in Otherness: Essays and Studies, 4 (2013), 1-21.

Heidegger, Martin, Identity and Difference, trans. by Joan Stambaugh (New York, Evanston, and London: Harper and Row, 1969).

, "The word of Nietzsche: 'God is dead'," in The Question Concerning Technology and Other Essays, ed. by David Ferrell Krell (New York and London: Garland, 1977).

Hyman, Gavin, "Must a Post-Metaphysical Political Theology RepudiateTranscendence? The Case of Gianni Vattimo," in The Journal for Cultural and Religious Theory, 8 (2007), 124-134.

Nietzsche, Friedrich, The Anti-Christ, trans. by R. J. Hollingdale (London: Penguin, 1990a).

Twilight of the Idols, trans. by R. J. Hollingdale (London: Penguin, 1990b).

Beyond Good and Evil, trans. by R. J. Hollingdale (London: Penguin, 1990c).

The Gay Science, trans. by Josephine Nauckhoff (Cambridge: Cambridge University Press, 2001).

O'Neill, Onora, The Bounds of Justice (Cambridge: Cambridge University Press, 2000).

Paton, H.J. The Moral Law: Kant's Groundwork of the Metaphysics of Morals (London: Hutchinson University Library, 1972).

Schneewind, J. B., “Autonomy, Obligation and Virtue: An Overview of Kant's Moral Philosophy," in The Cambridge Companion to Kant, ed. by Paul Guyer (Cambridge: Cambridge University Press, 1992).

Vattimo, Gianni. Verità e metodo (Milan: Bompiani, 1983).

The End of Modernity, trans. by Jon Snyder (Cambridge: The

Polity Press, 1988).

"Towards an Ontology of Decline," in Recoding Metaphysics, ed. by Giovanna Borradori (Evanston, Illinois: Northwestern University Press, 1988).

The Transparent Society, trans. by David Webb (Cambridge: The Polity Press, 1992).

(c) 2014 Matthew Edward Harris

http://www.kritike.org/journal/issue 15/harris december2014.pdf

ISSN 1908-7330

(cc) BY-NC 
The Adventure of Difference, trans. by Cyprian Blamires

(Baltimore: The John Hopkins University Press, 1993). Beyond Interpretation, trans. by David Webb (Cambridge: The Polity Press, 1997).

"The Trace of the Trace," in Religion, ed. by Jacques Derrida and Gianni Vattimo, trans. by David Webb (Cambridge: The Polity Press, 1998).

Belief, trans. by David Webb and Luca D'Isanto (Cambridge: The Polity Press, 1999). After Christianity, trans. by Luca D'Isanto (New York: Columbia University Press, 2002).

"After Onto-Theology: Philosophy Between Science and Religion," in Religion after Metaphysics, ed. by Mark Wrathall (Cambridge: Cambridge University Press, 2003). Nihilism and Emancipation, trans. by William McCuaig (New York: Columbia University Press, 2004).

"Toward a Nonreligious Christianity," in After the Death of God, ed. by Jeffrey W. Robbins (New York: Columbia University Press, 2007).

The Responsibility of the Philosopher, trans. by William McCuaig (New York: Columbia University Press, 2010).

"Heidegger and Girard," in Christianity, Truth, and Weakening Faith: a Dialogue, ed. by Santiago Zabala (New York: Columbia University Press, 2010).

A Farewell to Truth, trans. by William McCuaig (New York: Columbia University Press, 2011).

Vattimo, Gianni, Rorty, Richard and Santiago Zabala, “What is Religion's Future After Metaphysics?" in The Future of Religion, ed. by Santiago Zabala (New York: Columbia University Press, 2005).

Vattimo, Gianni and Santiago Zabala, "Ethics without Transcendence?," in Common Knowledge, 9 (2003), 399-405.

Vattimo, Gianni and Santiago Zabala, Hermeneutic Communism: from Heidegger to Marx (New York: Columbia University Press, 2011).

Welsch, Wolfgang, "The Human-Over and Over Again," in Weakening Philosophy: Essays in Honour of Gianni Vattimo, ed. by Santiago Zabala (Montreal \& Kingston, London, Ithaca: McGill-Queen's University Press, 2007).

Wiggins, David, Needs, Values and Truth (Oxford: Blackwell, 1991).

Wood, Allen, Kant's Ethical Thought (Cambridge: Cambridge University Press, 1999).

Williams, Bernard, Morality (Harmondsworth, Middlesex: Penguin, 1973).

(c) 2014 Matthew Edward Harris http://www.kritike.org/journal/issue 15/harris december2014.pdf 